\title{
Nganasan Children Literature: History and Specifics
}

\author{
Alexandra A. Sitnikova* \\ Siberian Federal University \\ 79 Svobodny, Krasnoyarsk, 660041, Russia
}

Received 21.01.2016, received in revised form 18.04.2016, accepted 19.08.2016

The paper presents the results of studying Nganasan fairy tales for children. The author traces the origin of Nganasan children's fairy tales back to the mythological epic tales of the Nganasan people (sitaby) and to the historical national traditions (diurymy). The author also looks into the possibility of applying morphological and semantic analysis to understanding Nganasan fairy tales, resulting in description of some aspects of the worldview of the Nganasan people, along with their moral and value judgments, which are transferred by children's literature to the younger generation.

Keywords: literature of the indigenous small-numbered peoples of the North, Nganasan folklore, Nganasan mythology, sitaby, Nganasan fairy tales, Nganasan worldview.

The work was implemented within the project "Creating a corpus of texts for children in their native languages (the Evenki, Nenets, Nganasan, Dolgan languages) as a way to preserve the unique cultural heritage of the indigenous small-numbered peoples of Krasnoyarsk Krai", supported by the Krasnoyarsk Regional Science Foundation.

DOI: 10.17516/1997-1370-2016-9-9-2005-2012.

Research area: theory and history of culture.

\section{Introduction}

In modern humanitarian sciences and practices (music festivals, documentary films, workshops for the production of objects of decorative and applied arts, etc.) the considerable attention is paid to the culture of the northern nomadic peoples, in particular, the culture of the indigenous peoples of Siberia. In part so much attention to this subject may be attributed to the fact that the northern nomadic peoples are a cultural "bridge" between the ancient primitive and "simple" way of life of human communities there and the currently "difficult" existence of human communities in urban life. This is also partly due to the uniqueness of the situation: in unsuitable for human life climates distinctive culture with their own languages, music, folklore, literature, etc. are not only preserved but even continue to develop. In part alarmist mood of the indigenous peoples' representatives and academics about the urgent need of salvation and perhaps the museum preservation of the remaining residues of northern cultures determine continuous reference of scientists to the topic.

(C) Siberian Federal University. All rights reserved

* Corresponding author E-mail address: sem_dobrianka@mail.ru 
This paper focuses on studying one of the indigenous cultures of the Siberian north, i.e. Nganasan culture - of the people inhabiting the Taimyr District of Krasnoyarsk Krai (Territory). The Nganasans are the small-numbered indigenous nation of the North accounting for less than 1000 people. More specifically, the author is interested in Nganasan children's literature representing the literary processing of folklore of this people. Children's literature is a valuable source for understanding attitudes toward the world existing among the Nganasan people. After all, children's literature, consisting mainly of fairy tales, is a translator of moral values of any nation.

The purpose of the study, the results of which will be laid out in this paper, was to describe the history of the formation of Nganasan children's literature and to reveal axiological specifics in Nganasan fairy tales.

\section{Survey Methodology}

The key methods of the study were the semantic and morphological analysis of literary texts of Nganasan fairy tales. Following V.Ya. Propp's method morphological analysis was aimed at identifying sustainable and recurring "units" (characters) in Nganasan fairy tales; it was an attempt to interpret the meaning of these morphological units. Taking an advantage of semantic analysis the author discovered the ontological and axiological meanings in Nganasan children's fairy tales.

During the study there were analyzed such tales as "The Girl and the Moon", "The Bears and the Old Man", "Morrede", "About Nganasan with three-sagene' Arms and his Son", "Lake of Death", "Why the Fox Has White Wool on the Chest", "The Sun's Daughter", "The Son of the Bea", "The Seagulls", "The Tale of SigaCannibal", "The Coward Deer". As well for understanding the history of Nganasan children's literature there were used materials of the corpus of Nganasan folklore and ethnographic texts collected in Nganasan settlements and translated into Russian in the village of Ust-Avam (Taimyr Autonomic Okrug) in 2003-2005 under the support of the Presidium of the Russian Academy of Sciences within the framework of the target program "Ethnic and cultural cooperation with Eurasia" (The Corpus of Nganasan ...). Among the texts there was a record of the story from the most popular Nganasan sitab (national mythological epic) "Seu Meliangana" and diurymy. Moreover, mythological legends and diurymy, which had served as a basis for the development of Nganasan children's literature, were investigated in the book "The Mythological Prose of Small-Numbered Peoples of Siberia and the Far East", compiled by E.S. Novikov (The Mythological Prose...).

Both in common and scientific understanding it has been long established that children's literature, especially fairy tales, is the best translator of the moral values of a nation. Therefore, referring to the study of Nganasan children's literature, the objective is to study the Nganasans' traditional values, a certain set of rules, helping them to survive in northern climates and in nomadic conditions.

\section{Related Literature}

There are almost no articles, papers and books devoted to the direct analysis of Nganasan children's literature, therefore, before describing the body of scientific texts, allowing to ascertain the relevant aspects of the present study, the author analytically approached and considered such units as "the history of Nganasan literature", "Nganasan folklore", "folklore of the indigenous peoples of Siberia and the North", "specifics of Nganasan literature".

In the thesis, researcher V.K. Biche-ool (2009) listed a large number of scientists and their works devoted to the study of the culture and 
way of life of the indigenous northern peoples, as well as various aspects of Nganasan culture per se, such as archeology, linguistics, music, art, folklore, etc. In the context of this study the most interesting is the scientific literature dedicated to the Nganasans' worldview (Grachev, 1983) and the study of Nganasan folklore (Labanauskas, 1992). No less significant are the studies by O.E. Dobzhanskaia, the results of which are stated in such articles as "On the Present State of the Practice of Performing Nganasan Epic and the Need to Preserve the Epic Heritage of the Nation" (2013) and "The History of the Nganasan Shamanism" (2013), as this source gives classification of the Nganasan folklore heritage. Description of Nganasan traditions of performing traditional folk tales from and the features of recording in writing Nganasan works are found in the paper by E.A. Khelimskii "The Nganasan Language as Literary one: Reflections on the Literary Languages" (2000).

\section{Progress in Research and Results}

The history of Nganasan children's literature

In all cultures, literature has its roots in mythology, folklore and oral epic tradition. For Nganasan literature its relationship with the folklore is particularly relevant, since the transformation of the Nganasan language in the written literary one happened artificially in the 1990s, when the Soviet scientists designed the alphabet for the Nganasans, which was synthesized with Russian for the convenience of the media public informing in their native language. That is why literary works in Nganasan are mostly texts not of a single author, but rather recording of folklore tales - sitaby (mythological epic) and diurymy (historical legends). These folklore works are of ancient origin; they tell both about the birth of the Nganasan people (according to one version, from the deer) and about the national heroes of antiquity, with one of the central characters of the Nganasan epic called "Seu Meliangana". Oral epics were sung by the Nganasans during the polar night in tents near the fire, that is in almost complete darkness, and, as pointed out by researcher E.A. Khelimskii, in principle, the Nganasan epic is very auditory in its nature. In particular, in telling Nganasan epics the role of the audience was very important as they were shouting their opinions (approval or outrage) about the behavior of certain characters, or asked performers about something; also the audience expressed their opinions with facial expressions showing whether they were happy or unhappy with the events happening in the epic. Indeed, when the modern reader reads the field recordings of folk Nganasan tales, some events in the text are hardly understood by reading only as their narrator can transmit these events with the mimic only or replying someone's shouting from the audience. It stands to reason that Nganasan epic tales were told by shamans or skilled storytellers.

As well as in many cultures, Nganasan children's literature is represented by fairy tales, which have a clear descent from the epic and mythological tales. Consequently, it is difficult to speak about Nganasan special children's literature, as the epic stories were told at the same time for both children and adults, so Nganasan fairy tales demonstrate the contradictory and not always understandable by urban humans moral. The appearance of Nganasan children's literature probably happened in Soviet times, when there was a process of active integration of all the diversity of national cultures into the single Soviet cultural space. So, at this time there were gathered whole collections of tales of various peoples of Siberia and, in particular, the Nganasans.

In the analysis of Nganasan tales and some mythological tales (sitaby), from which they originate, the author had the chance to identify 
the most frequent characters in these tales, their key motives and as a result to describe axiology of Nganasan culture in the form in which it is transmitted to the younger generation.

1. One of the key standard introductions for Nganasan stories is the situation of matchmaking: when a young man from one nomadic camp woos a girl from other nomadic camp, namely asks for a wedding permission from the girl's parents. It is a pretty traditional introduction for fairy tales all around the world. But, for example, whereas in the Russian fairy tales girl's parents send the young man to distant lands to go through trials and prove his ability to become a husband, in the Nganasan fairy tales the girl's parents quit their camp and begin to run away, while the young man rushes to pursue them. One can assume that the Nganasan hero is being tested for the ability to roam on a sledge, lead a nomadic life, navigate through the tundra not worse than the bride's family.

2. One frequent character of Nganasan legends and fairy tales is a shaman, and a fairy tale very often offers a story of human evolution told by a shaman. Nganasan tales form a little mundane attitude towards shamans, as they are lame characters (without a leg or an arm, blind, or the children who were supposed to die in childhood) who use either their own craftiness (as in the fairy tale "Three Brothers") or cunning and stubbornness of their parents ("Lake of Death") to become shamans rather than to perish.

3. Nganasan fairy tales reflect an interesting model of the interaction between man and nature. Nature seems hostile to man: lakes try to suck a human to the bottom, endless empty clay soils force a way worn man to run the tired deer in search of food, mosquitoes do not give a person any chance to relax. People, in turn, do not fight nature, do not try to alter it, and instead of this they try to persuade it not to be so cruel, to appease it, to give it any gifts, trade with it

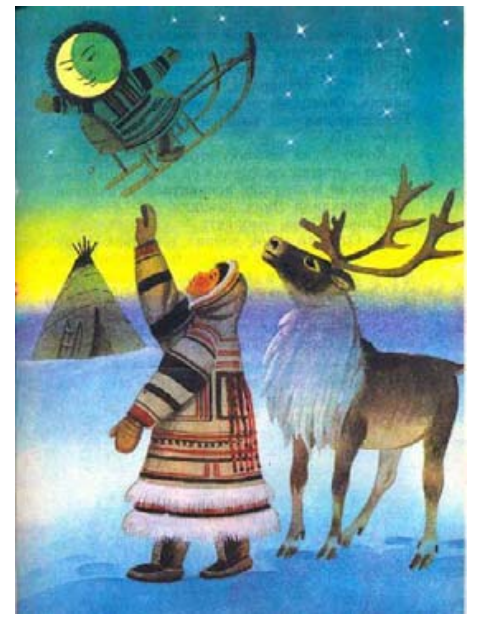

Fig. 1. Illustration to the fairy tale "The Girl and the Moon" by Gusarov

(instead of the children's lives they offer deer and so on), try to outwit it. All these activities most likely reflect the relationships of the Nganasans with nature as a whole.

4. Other frequent characters of Nganasan tales are giants, ogres or strange people with eyes on their shoulders and mouth on their stomach. The profession of these characters can often be interpreted as intermediary between man and nature. Sometimes the description of strange people with eyes on their shoulders has such epithets as "with the roots of the trees on the head", which suggests that these characters in Nganasan literature are a sort of centaurs, "man-deer", "man-bears". Being as if the nature ambassadors these "centaurs" are the antagonists, since, as it was already indicated above, in Nganasan culture nature is hostile to human.

5. Furthermore, one more distinctive feature of Nganasan fairy tale is characters' amenability and external absence of conflict: a Nganasan hero often does not directly oppose his torment, injustice and ill-treatment, but prefers to accumulate anger with the abuser quietly, waiting for the right moment for revenge or the moment when the very fate will avenge the hero's injuries (one part of the legend of "Seu Meliangana"). 
6. Many Nganasan fairy tales, like fairy tales of other peoples of the world, embody the history of the appearance of certain realities on the Earth, that means they are to explain the children the reasons for the existence of certain phenomena, often specific to tundra climate. These are the stories about the origin of mosquitoes ("The Tale of Siga-cannibal"), the reasons why the wolves eat deer ("The Tale of the Cowardly Deer"), white spots on the fox's neck, etc.

Apart from the morphological analysis, identifying key characters and motifs of Nganasan fairy tales the researchers need to pay attention to the lexical and syntactical specifics of Nganasan fairy tales. Many realities of Nganasan daily life and culture do not have analogues in the Russian

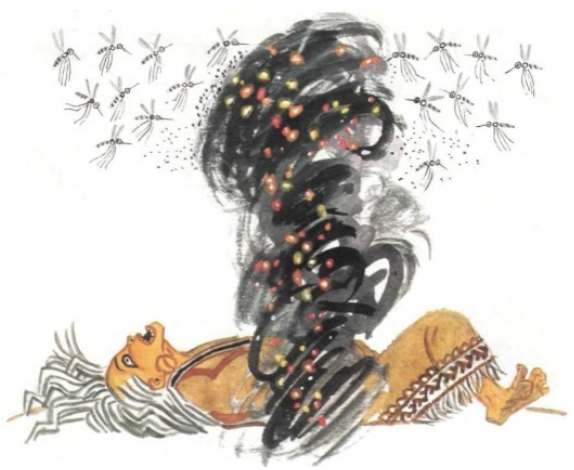

Fig. 2. Illustration for "The Tale of Siga-cannibal" by V.N. Losin

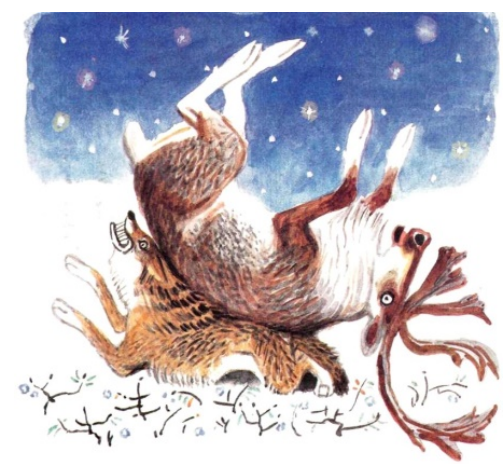

Fig. 3. Illustration for "The Tale of the Cowardly Deer" by V.N. Losin language; they are not translated, and in texts there are incomprehensible to the reader words, if the reader is unfamiliar with the northern way of life. For instance, these words are argishit' (to roam on a sledge with deer), argish (nomadic wagon), vazhenka (female reindeer). Other features of storytelling concerning Nganasan epic tales also left their mark on the specifics of the literary version of Nganasan fairy tales: for example, their written form often has forms from the colloquial language (simple, naïve turns of speech speed) like "well", "what", etc.; even reading the written variant one can gain a clear sense that the fairy tale is told live - by a performer. This sense is created by the frequent presence of such vernacular phrases as slushai$k a$ (encouraging to listen), a sam-to kak dumaesh' (what do you think yourself?) and other similar phrases.

\section{Conclusion}

Thus, the present study attempted to identify the specifics of Nganasan children's literature as previously there was a virtual absence of the scientific literature in reference to the subject. As a result, it was found that Nganasan children's literature was formed as a separate phenomenon in Soviet times, during the "gathering" and recording in the written form of fairy tales of the indigenous peoples of the North and Siberia. The origin of Nganasan children's literature is mythological national epic stories (sitaby) and historical tales of the Nganasan people (diurymy). Despite the procession of folk sources in writing, children's literature has retained some of the features of the Nganasan narrative tradition: colloquial character, unique words from the Nganasan language, which denote the realities of the North, "naïve" appeals to listeners, etc. Besides this, fairy tales partly reflect axiology of the Nganasan people: the most important human qualities are the ability to move quickly across the tundra, to wander in search of 
the best places; the ability to persuade nature, to "bargain" with it in an attempt to win a better lot; the ability to hide and wait for the right moment (often for many years) like in the case of enmity and successive revenge. Fairy tales disclose the nature of the relationship between the Nganasans and nature in full: most of nature phenomena are hostile to man and wish the death of people (like the moon, lakes, rivers, ice, etc.), so a human has to constantly bring gifts to nature for the sake of haggling over the very chance to survive on the Earth.

\footnotetext{
Translator's note: one Russian sagene is old measure of distance equal to 2,13 m.
}

\section{References}

Biche-ool, V.K. (2009). Kul'tura hganasan: istoriko-kul'turnyi analiz [The Nganasan culture: historical and cultural analysis]. Abstract of Thesis of Candidate of Cultural Studies. Chelyabinsk, available at: http://cheloveknauka.com/kultura-nganasan-istoriko-kulturologicheskiy-analiz

Corpus of the Nganasan folklore texts, available at: http://www.iling-ran.ru/gusev/Nganasan/ index.php

Dobzhanskaia, O.E. (2013). Istoriia nganasanskogo shamansva [History of Nganasan shamanism], In Tomskii Zhurnal LING i ANTR [Tomsk Journal LING \& ANTHROPO], 2, available at: http://ling. tspu.edu.ru/files/ling/PDF/articles/dobzhanskaya_o._e._100_105_2_2_2013.pdf

Dobzhanskaia, O.E. (2013). O sovremennom sostoianii praktiki epicheskogo ispolnitel'stva u nganasan i neobkhodimosti sokhraneniia epicheskogo naslediia naroda [On the present state of the Nganasan practice of performing epic and the need to preserve the epic heritage of the nation], In Epicheskoe nasledie i dukhovnye praktiki v proshlom i nastoiashchem: sbornik statei [Epic heritage and spiritual practices of the past and the present: collected works]. Moscow, IEA RAS, 23 - 33, available at: http://static.iea.ras.ru/books/Kharitonova_15.2.pdf

Dolgikh, B.O. (1976). Mifologicheskie skazki i istoricheskie predaniia nhanasan [The mythological fairy tales and historical legends of the Nganasans]. Moscow.

Epicheskie skazaniia sitaby u nganasan [The Nganasans' epic tales sitaby], available at: http:// www.culture.ru/objects/379/epicheskie-skazaniya-sitabi-u-nganasan

Gracheva, G.N. (1983). Traditsionnoe mirovozzrenie okhotnikov Taimyra (na materialakh nganasan XIX - nachala XX veka [Traditional worldview of Taimyr hunters (on the Nganasan materials in the $19^{\text {th }}$ - early $20^{\text {th }}$ century)]. Leningrad, Nauka, available at: http://www.kunstkamera. ru/lib/rubrikator/03/03_03/gracheva_1983/

Il'beikina, M.A. (2014). Osobennosti vizual'no-antropologicheskikh issledovanii indigennykh narodov [Features of the visual-anthropological studies of the indigenous peoples], In Sovremennye problemy nauki i obrazovaniia [Modern problems of science and education], 4, 594.

Khelimskii, E.A. (2000). Nganasanskii iazyk kak literaturnyi: razmyshleniia po povodu literaturnykh iazykov [The Nganasan language as a literary one: reflections on the literary languages], In Komparativistika, uralistika: lektsii i stat'i [Comparative studies, Uralic Studies: lectures and papers], 161-163, available at: http://www.philology.ru/linguistics3/khelimsky00c.htm

Khudozhestvennyi mir Sibiri. Narodnye skazki nganasan [Artistic world of Siberia. The Nganasans' folk tales], available at: http://museumsrussian.blogspot.ru/2012/12/blog-post_21.html

$$
-2010-
$$


Kistova, A.V. (2013). Stanovlenie filosofii kul'tury kak metodologicheskoi osnovy gumanitarnogo znaniia [The formation of the philosophy of culture as a methodological basis of humanitarian knowledge], In Sovremennye problemy nauki i obrazovaniia [Modern problems of science and education], 1, 401.

Kolesnik, M.A. (2014). Obzor izucheniiaa fol'klora korennykh narodov severa [Review of the study of folklore of the indigenous peoples of the North], In Litera, 3, 9-11, available at: http://e-notabene.ru/fil/article_13998.html

Koptseva, N.P., Bralkova A.V., Gerasimova, A.A., Govorukhina, Iu.A. et al. (2015). Novaia artkritika na beregakh Eniseia [New art criticism on the banks of the Yenisei river]. Krasnoyarsk, Siberian Federal University.

Koptseva, N.P., Nevol'ko, N.N., and K.V. Reznikova (2013). Formirovanie etnokul'turnoi identichnosti v sovremennoi Rossii s pomoshch'iu proizvedenii natsional'nogo iskusstva (na primere evenkiiskogo eposa i dekorativno-prikkladnogo iskusstva) [The formation of ethnocultural identity in modern Russia with the help of the works of national art (on the basis of the Evenk epic, arts and crafts)], In Pedagogika iskusstva [Pedagogy of art], 1, 1-15.

Koptseva, N.P., Seredkina, N.N. (2013). Konstruirovanie pozitivnoi etnicheskoi identichnosti $v$ polikul'turnoi sisteme [Construction of a positive ethnic identity in a multicultural system]. Krasnoyarsk, Siberian Federal University.

Koptseva, N.P., Sertakova E.A., Il'beikina, M.I., Zamaraeva, Iu.S., Libakova, N.M., Bakhova, N.A., Luzan, V.S., Reznikova, K.V., Kistova, A.V., Pimenova, N.N., Nevol'ko, N.N. (2011). Kul'tura korennykh $i$ malochislennykh narodov Severa $v$ usloviiakh global'nykh transformatsii [The culture of the indigenous and small-numbered peoples of the North in the conditions of global transformations]. St. Petersburg, $174 \mathrm{p}$.

Labanauskas, K.I. (1992). Fol'klor narodov Taimyra [The folklore of the peoples of Taimyr]. Dudinka, $62 \mathrm{p}$.

Libakova, N.M., Sertakova, E.A. (2014). Kul'turologicheskoe issledovanie korennykh malochislennykh narodov Severa Krasnoiarskogo kraia: rezul'taty ekspertnogo interv'iu [Cultural studies of the indigenous small-numbered peoples of the North of Krasnoyarsk Krai: results of the expert interviews], In Sovremennye problemy nauki i obrazovaniia [Modern problems of science and education], 4, 598.

Nganasan fairy tales, available at: http://www.fairy-tales.su/narodnye/nganasanskie-skazki/

Novikov, E.S. (eds.) Mifologicheskaia proza malykh narodov Sibiri i Dal'nego Vostoka [The mythological prose of small peoples of Siberia and the Far East], available at: http://www.ruthenia.ru/ folklore/novik/index.htm

Pimenova, N.N. (2015). Korennye malochislennye narody v sovremennoi situatsii: ob'em i soderzhanie poniatiia [The indigenous small-numbered peoples in the current situation: the scope and content of the concept], In Sotsiodinamika [Sociodynamics], 1, 112-134, available at: http://e-notabene. ru/pr/article_14249.htmlDOI: 10.7256/2409-7144.2015.1.14249.

Razumovskaia, V.A. (2012). Izomeriia v ligvistike i perevodovedenii: rasshirenie kategorial'noi paradigm [Isomerism in linguistics and translation studies: an extension of the categorical paradigm], In Iazyk i kul'tura [Language and culture], 4 (20), 49-61.

Razumovskaia, V.A. (2015). Kognitivnye osobennosti avtorskogo perevoda poezii [Cognitive features of the author's translation of poetry], In Kognitivnye issledovaniia iazyka [Cognitive studies of language], 22, 521-523. 
Reznikova, K.V. (2014). K voprosu ob utochnenii poniatii "etnos" i "etnichnost" [On the issue of clarifying the concepts of "ethnos" and "ethnicity"], In Sotsiodinamika [Sociodynamics], 12, 90-102, available at: http://e-notabene.ru/pr/article_13913.html DOI: 10.7256/2409-7144.2014.12.13913.

Reznikova, K.V.(2016). K voprosu ob epicheskom kul'turnom nasledii korennykh malochislennykh narodov Krasnoiarskogo kraia [On the issue of the epic cultural heritage of the indigenous smallnumbered peoples of Krasnoyarsk Krai], In Litera, 2, 20-34, available at: http://e-notabene.ru/fil/ article_18917.html DOI: 10.7256/2409-8698.2016.2.18917.

Zamaraeva, Iu.S. (2015). Global'nye transformatsii, kotorye perezhivaiut indigennye narody Severa [Global transformations that concern the indigenous peoples of the North], In Sovremennye problemy nauki i obrazovaniia [Modern problems of science and education], 1-1, 1882.

\title{
Нганасанская детская литература: история и специфика
}

\author{
А.А. Ситникова \\ Сибирский федеральнылй университет \\ Россия, 660041, Красноярск, пр. Свободный, 79
}

\begin{abstract}
В статье представлены результаты исследования нганасанских детских сказок. Раскрыта история происхождения нганасанских детских сказок от мифологических эпических сказаний народа (ситабов) и из исторических национальных преданий (дюрымыл). Апробирована возможность приложения морфологического и семантического анализа для понимания нганасанских сказок, в результате чего описаны отдельнье аспекть мироотношения нганасанского народа, а также морально-ценностные установки, которые транслируются детской литературой подрастающему поколению.
\end{abstract}

Ключевые слова: литература коренных малочисленных народов Севера, мифология коренньх малочисленных народов Севера, нганасанский фольклор, мифология нганасан, ситабы, нганасанские сказки, мироотношение нганасан.

Работа выполнена в связи с проектом «Создание корпуса текстов для детей на родных языках (эвенкийский, ненецкий, нганасанский, долганский) как способ сохранения уникального культурного наследия коренных малочисленных народов Красноярского края», поддержанньм Красноярским краевым фондом науки.

Научная спещиальность: 24.00.01 - теория и история культурыл. 